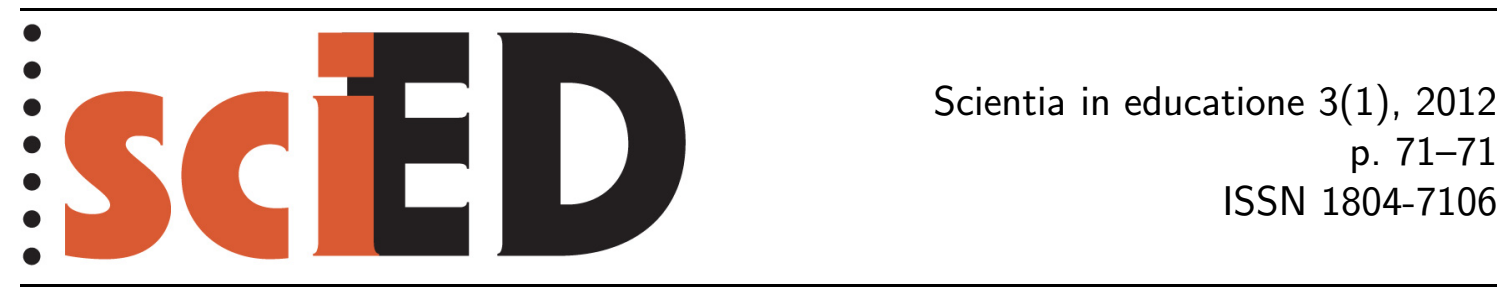

\title{
European Journal of Health and Biology Education
}

Na poli biologického vzdelávania a výchovy k zdraví vznikol nový medzinárodný časopis European Journal of Health and Biology Education so sídlom v Turecku a vychádzajúci v nakladatel'stve AkademikPlus.

Časopis si kladie za ciel’ poskytnút priestor pre výskum v oblasti biologického vzdelávania a výchovy $\mathrm{k}$ zdraví. Časopis plánuje publikovat recenzované príspevky teoretického a výskumného charakteru. Príspevky by mali byt napísané jasne a zrozumitelne, aby našli čo najviac čitatelov. Práce výskumného typu by mali ponúkat originálny výskum, správnu metodologické ukotvenie, adekvátnu teoretickú podporu a význam v medzinárodných kruhoch.

Casopis prijíma okrem teoretických a výskumných štúdií takisto recenzie na monografie v oblasti biologického vzdelávania a výchovu ku zdraví. Okrem toho sú súčastou obsahu tiež správy z konferencií, ktoré sledujú ciel časopisu.

Redakčnú radu tvorí tím odborníkov na biologické vzdelávanie a výchovu ku zdraví nielen z Európy, ale aj z Austrálii a z Nového Zélandu. Pri výbere členov redakčnej rady sa editor riadil ich odbornou kompetentnostou a vedecko-výskumnou aktivitou v odbore. Pozitívnym javom je, že súčastou časopisu sú dvaja zástupcovia akademickej obce z Českej republiky, jeden vo funkcii editora a jeden ako člen redakčnej rady.

Casopis plánuje v roku 2012 vydat dve čísla, prvé v júli, s uzávierkou príspevkov v polovici mája. Druhé na konci roka. Cielom časopisu je prienik do medzinárodne uznávaných databáz, ako Copernicus, či Scopus. Bližšie informácie pre autorov je možné nájst’ na webovej stránke časopisu: http://www.akademikplus.com/ejhbe/

Milan Kubiatko editor

Milan Kubiatko - E-mail: mkubiatko@gmail.com

Masarykova univerzita v Brně, Pedagogická fakulta

Institut výzkumu školního vzdělávání

Poříčí 31, 60300 Brno, Česká republika 